\title{
Effects Of RFID Technology On Efficiency And Profitability In Retail Supply Chains
}

Seungjae Shin, Mississippi State University, USA

Burak Eksioglu, Mississippi State University, USA

\begin{abstract}
Ten years have passed since Wal-Mart's public announcement about its RFID technology adoption plan in 2003. Some large competitors of Wal-Mart in the U.S. retail industry jumped on the trend of RFID technology adoption. However, there has been a slowdown of RFID technology adoption since 2008. Many U.S. retailers do not consider adopting RFID technology because of the uncertainty of return on investment and the lack of business cases demonstrating its profitability or efficiency. This study investigates whether RFID companies have better financial performance ratios in the U.S. retail supply chains. RFID retailers have significantly lower daysin-inventory and lower per-employee costs. Compared with pre-RFID, the RFID retailers do not improve profit ratios after they adopted it, but their days-in-inventory ratio and sales efficiency improve significantly. Panel data regression analyses show that inventory management efficiency does impact gross margins, but the impact of cost efficiency is negligible. RFID retailers have a positive relationship with gross margin increases. In summary, it could be stated that introducing RFID improves inventory management efficiency but we do not know yet if RFID technology adoption also contributes to profitability in U.S. retail industry.
\end{abstract}

Keywords: RFID Technology; Retail Supply Chains Profitability

\section{INTRODUCTION}

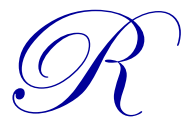

adio frequency identification, or RFID, technology allows businesses to share accurate information about inventory data and the supply chain network's product flow between suppliers and retailers. RFID technology allows for wireless automatic scanning, which can reduce scanning error rates as well as the man-power required to scan the products. The technology can also reduce stockouts, which can lead to improved customer satisfaction and reduced revenue loss.

RFID technology is a global phenomenon that began in the U.S. retail industry. RFID technology first came into the spotlight when Wal-Mart publicly announced its plan to use the technology in 2003 (Hunt, Puglia, \& Puglia, 2007). Wal-Mart was the first to issue a RFID technology mandate, which required its top 100 suppliers to put RFID tags on their pallets and cases beginning in January 2005 (RFID Journal, 2003). The mandate was soon expanded to 300 suppliers (Hunt et al., 2007). Wal-Mart announced in 2007 that it would charge Sam's Club suppliers a \$2 penalty for each pallet without a RFID tag shipped to distribution centers beginning January 2008 (Weier, 2008).

Target, one of Wal-Mart's biggest competitors, soon issued its own RFID technology mandate for its top suppliers. The suppliers were required, beginning in 2005, to apply RFID tags to any pallets and cases sent to Target's distribution centers (RFID Journal, 2004). After that, other major retail companies such as Kroger, Home Depot, Albertson, BestBuy, CVS, and Walgreens announced their similar mandates for their businesses to adopt RFID technology (Supply Insight Inc., 2006).

In addition, the U.S. Department of Defense (DOD) published an RFID mandate, effective March 1, 2007, to its 43,000 suppliers (Malone, 2005), and the Food and Drug Administration (FDA) published its guidelines about RFID technology adoption for the drug-distribution system (Whiting, 2004). 
Use of RFID technology can improve inventory accuracy and supply chain efficiency, which can improve profitability of retail companies. However, there are concerns about RFID's return on investment (ROI) for businesses, and the RFID adoption rate slowed after 2008 (Edwards, 2008). No certain evidence demonstrates that incorporating RFID technology results in a profit increase. Even if RFID industry experts and academic researchers argue that the RFID technology is a disruptive technology to transform supply chains into more efficient systems, skepticism remains that the RFID technology is an upgraded barcode system with a huge cost and little benefit (Collins et al., 2010). In addition, many small and medium enterprises (SMEs) are reluctant to adopt RFID technology because they perceive it as unprofitable and risky. While large enterprises are likely to enjoy the economy of scale in RFID implementation, SMEs claim that RFID technology is cost-ineffective because of low demands and high up-front implementation cost (Lee \& Lee, 2010).

Most empirical analyses of RFID studies focus on supply chain efficiency using the RFID technology. Even if there are lots of RFID case studies for supply chain efficiency, it is not easy to find how much the RFID technology improves cost-savings and profit-boosting. There is not a firm connection between supply chain efficiency and RFID adopted companies' profitability. There is only one empirical study (Chang, 2011) which examines the relationship between RFID technology adoption and manufacturing companies' financial performances.

In this paper, the authors focus on the U.S. retail industry and categorizes members of the retail industry into two groups, RFID technology adopted retail companies (RFID companies) and non-adopted retail companies (non-RFID companies). These two groups are compared on the basis of financial performance, inventory management efficiency, and per employee efficiency. In addition, the authors try to find a relationship between those efficiencies and profitability in the U.S. retail industry. This study gives industry practitioners a firm foundation of profitability and efficiency of the RFID technology adoption.

This study begins with a brief literature review and RFID implementation issues, followed by a detailed listing of the research approach, including the data collection procedure, research hypotheses, and research methods. After the discussion about outputs comes the conclusion section.

\section{LITERATURE REVIEW}

RFID technology is formally defined as "the use of wireless systems to identify, capture, and transmit information from tagged objects to enterprise systems" (Visich, Khumawala, \& Reyes, 2009; Bhatacharya Chu, \& Mullen, 2010). Hardgrave, Langford, Waller, \& Miller (2007) study how accurate inventory records are when RFID tags are used. According to their studies, the retailers' average stockout rate is $8 \%$, and $4 \%$ of annual sales are expected to be reduced because of stockouts. They measure stockout rates of tagged items and untagged items in five categories. Except for the furniture category, RFID tagging is more effective in reducing stockouts. Researchers estimate a $0.7 \%$ potential sale increase because of stockout rates' reduction. Kok, Donsekaar, and Woensel (2008) study the inventory policy including both inventory shrinkage and the impact of RFID technology using break-even analysis. They find that break-even prices of RFID tags are highly related with the value of the items that are lost and shrinkage fraction.

Visich et al. (2009), Sarac, Absi, \& Dauzere-Pere (2010), Bhattacharya (2012), and Zhu, Mukhopadhyay, \& Kurata (2012) analyze existing academic papers about companies adopting RFID technology. Visich et al. (2009) find that RFID technology can reduce stockouts, improve inventory accuracy, increase sales, and speed up the receipt of goods in retail stores. Bhattacharya (2012) retrieves 630 RFID related papers between 2006 and 2009. She analyzes those papers by content analysis methods and explained the benefits of RFID technology on retail industry: better management of inventory, improved security, increased operational efficiency, increased visibility, and reduced cost. Bhattacharya (2012) argues that retailers, except for large ones, are reluctant to adopt RFID because most retailers are not certain about the benefits of RFID technology against a huge up-front investment cost as well as limited internal skills to execute innovative RFID-enabled strategies. Sarac et al. (2010) review 142 references published by 2009 , which are relevant to the impacts of RFID technology on supply chain management. They categorize them into analytical model papers, simulation model papers, case-studies and experiments papers, and ROI analysis papers. In each category, they describe output of analysis and benefits of RFID technologies. Zhu et al. 
(2012) also do a rich review of published academic papers of RFID technology. They discuss management concerns and technical issues of RFID technology applications. They list RFID technology application examples in retail, food and restaurant, healthcare, travel industries, and library services.

Soon and Gutierrez (2008) argue that retailers have the power to force their supply chain networks to use RFID technology because the retailers have significant benefits over manufacturers due to reduced inventory, lower labor costs, and stockout reduction. Jeong and Lu (2008) examine the impact of the RFID investment announcements on the market value of the firms, and the research demonstrates there is a positive abnormal return on those investment announcements. Lee and Lee (2010) develop a RFID investment evaluation model and analyze the impact of RFID technologies on the cost savings. They find that economy of scale would be applied to RFID project. Chang (2011) examines manufacturing companies that adopted RFID technology. He chooses 62 paired data sets, each of which has a manufacturing company with RFID technology and a competing manufacturing company without RFID technology. He finds that RFID technology offers significant benefits for firms through improved inventory ratios and sales efficiency, which translates into higher profit for the firms.

The most popular research method in empirical RFID technology studies is to conduct a survey for key members such as information technology managers or operation managers (Park, Koh, \& Nam, 2010; Li, Godon, \& Visich, 2010; Zelbst, Green, \& Sower, 2010; Osyk, Vijayaraman, Srinivasan, \& Dey, 2012). Osyk et al. (2012) survey the warehousing industry and find that the companies are less optimistic about RFID implementation, and return on investment is the number one concern. Zelbst et al. (2010) survey 122 manufacturing companies and find that utilizing RFID technology directly impacted manufacturers' operational performance. Li et al. (2010) survey 49 members of Association of Operations Management Rhode Island Chapter and discover that financial concerns and the lack of business examples are the major reasons they are not considering implementation of RFID technology. Park et al. (2010) compare survey results from the U.S. and Korea, which show that there is no significant difference in the perception of importance of RFID technology, the benefits and risks of RFID, and RFID's impact on business performance between the two countries.

\section{DATA COLLECTION}

This study uses the Compustat database to obtain annual financial statements for U.S. retail companies, including balance sheets and income statements. In addition, the data for the number of full-time employees is added. NAICS, the North America Industry Classification System, is the U.S. industry classification standard used in the federal statistics. The companies in the U.S. retail industry have a NAICS code beginning with 44 and 45 . Between 2004 and 2011, there are 267 North American companies in the Compustat database that have an industry sector in retail. Among them, 141 companies are selected based on two criteria: (1) Each has eight years of financial data, from 2004 through 2011, listed in the Compustat database, and (2) each is listed in a traditional U.S. stock market, including NYSE, NASDAQ, or AMEX.

Some U.S. retail companies are delisted during this period, voluntarily or forcefully. The Sarbanes-Oxley Law of 2002 (SOX), which was established to prevent public company fraud, imposes many compliances and rules to the publicly traded companies. To avoid new requirements by the SOX, some of the publicly traded companies are acquired by a privately held company, which means delisting themselves from the stock markets (Bartlett, 2008). The financial crisis of 2007-2008 turned the U.S. economy downward severely, leading to the global recession. The U.S. stock market crashed and big financial companies collapsed or were bailed out by U.S. governments (Senbet \& Gande, 2009). Many companies are delisted by bankruptcy or failure to meet the minimum requirements, such as at least $\$ 25$ million market capitalization or average closing stock price with below $\$ 1$ over 30 trading days (Graff, 2008). The U.S retail industry also suffered with sales declines during the financial crisis. The authors want to choose retail companies that survive in the U.S. market on a long-term basis, which makes the above two as company selection criteria.

No official document shows when and which companies adopted the RFID technology for their supply chain operation. The publicly traded companies in U.S. stock markets must follow disclosure of material events affecting a company for investors' decision-making, which is a part of the U.S. Security and Exchange Commission (SEC) regulation. Because RFID adoption needs significant capital expenditure, the decision to invest or not invest 
in the RFID technology is a significant event to be published (Jeong \& Lu, 2008). Some retailers announce their RFID implementation in their annual reports to the public or issue a press release about their use of RFID technology. Some developers of RFID technology produce RFID case studies based on their customer company's experiences.

The authors try to find the RFID news using keywords such as RFID, stock ticker symbol, and/or names of 141 companies in the following methods: (1) Google key word searching (http://www.google.com), (2) key word searching in RFID article database from RFID Journal (http://www.rfidjournal.com), which is a leading RFID bimonthly journal magazine as a source of RFID news and information, (3) article searching in online magazines of supply chain/logistics/retail, and (4) key word searching in press release database from BusinessWire (http://www.businesswire.com).

Altogether, out of the 141 companies selected for the study, only 24 have a record of using RFID technology in their business during the periods of 2004-2011. The authors classify retailers that use the RFID technology only for anti-shoplifting or theft prevention without integrating their supply chain management systems as a non-adopted company. Some of major U.S. retailers such as Wal-Mart, Macy's, and JC Penny, upgrade their RFID projects to implement item-level RFID (McBeath, 2013). Some delays of item-level RFID project exist because of complexity of large scale project (Supply Chain Digest, 2013), but there is no public announcement for stopping RFID adoption. The authors assume that once retailers start their RFID project, it is considered as a continuous project.

If more than one article exists about the same RFID investment announcement in many sources, the earliest article and RFID Journal article is chosen as a source of RFID technology adoption. Table 1 presents the number of retail companies with RFID technology adoption in each year. The year 2006 is a boom for RFID adoption and since 2008, the cumulative number of companies with RFID adoption has been stable. Even though this study has eight years of data between 2004 through 2011, the data from 2008 through 2011 is mainly used for analysis.

Table 1: Number of RFID Adopted U.S. Retail Companies in $2002 \sim 2011$

\begin{tabular}{|l|c|c|c|c|c|c|c|c|c|c|}
\hline & $\mathbf{2 0 0 2}$ & $\mathbf{2 0 0 3}$ & $\mathbf{2 0 0 4}$ & $\mathbf{2 0 0 5}$ & $\mathbf{2 0 0 6}$ & $\mathbf{2 0 0 7}$ & $\mathbf{2 0 0 8}$ & $\mathbf{2 0 0 9}$ & $\mathbf{2 0 1 0}$ & $\mathbf{2 0 1 1}$ \\
\hline $\begin{array}{l}\text { Number of RFID } \\
\text { Adopted Retailers }\end{array}$ & 1 & 1 & 2 & 5 & 10 & 3 & 0 & 1 & 1 & 0 \\
\hline Cumulative Number & 1 & 2 & 4 & 9 & 19 & 22 & 22 & 23 & 24 & 24 \\
\hline
\end{tabular}

The total number of data observations in the data set is 1,128 , which is made up of 141 companies over 8 years. As mentioned earlier, each company has its own schedule for RFID adoption. According to RFID adoption announcement, the data for RFID companies can be divided by pre-RFID and post-RFID. For example, Wal-Mart has 8 post-RFID data and 0 pre-RFID data because its announcement was done in 2003. The number of data for post-RFID of all 24 RFID companies is 147 . Table 2 presents based on the grouping by post-RFID and pre-RFID.

Table 2: Data Set with Pre-RFID and Post-RFID

\begin{tabular}{|l|c|c|c|}
\hline & RFID Retailers (24) & Non-RFID Retailers (117) & Total U.S. Retailers (141) \\
\hline post-RFID & 147 & 0 & 147 \\
\hline pre-RFID & 45 & 936 & 981 \\
\hline Total & 192 & 936 & 1128 \\
\hline
\end{tabular}

Financial ratios are good tools to compare two individual companies or two groups of companies in the same industry. Using the above data sets, six financial ratios, categorized into three groups, are calculated: (1) profitability group, (2) inventory management efficiency group, and (3) per employee efficiency group.

Two income concepts are used in financial statements; gross income and net income. Gross income is sales minus cost of goods sold, and net income is gross incomes minus operating expenses, interests, and taxes. The profit ratios associated with these two incomes are gross margin and profit margin. The gross margin, or GM, is gross income divided by sales. The profit margin, or PM, measures net income as a percentage of sales. 
Inventory management ratios are days-in-inventory, or DII, and inventory-to-sales ratio, or ISR. DII is the most popular ratio to measure the efficiency of a company in managing its inventory (Fraser \& Ormiston, 2010). DII is calculated by 365 days divided by inventory turnover. In other words, DII measures the average number of days a company holds inventory before selling it. The DII ratio shows how quickly retailers convert their inventory into sales; the lower the DII is, the faster inventory sells, the lesser operating money is tied up in inventory. While DII ratio increases in the economy downturn, this ratio decreases in the economy boom. ISR, inventory divided by sales, measures the relationship between a retailer's inventory and its sales volume. A higher ISR ratio means that inventory is increasing relative to sales, indicating retailer's sale is slowing. Therefore, the DII and ISR ratios could be a litmus paper to diagnose retailer's performance on sales.

The last group of ratios relates to per-employee efficiency to determine the effects of RFID technology on efficiency. Per-employee revenue, or PER, and per-employee cost, or PEC, are, respectively, sales and cost divided by the number of full-time employees. Table 3 presents descriptive statistics for the above six ratios. There are 18 missing data items for number of full-time employees. Thus, the total number of PER and PEC is 1110.

Table 3: Descriptive Statistics for Financial Ratios

\begin{tabular}{|l|c|c|c|c|c|}
\hline & $\mathbf{N}$ & Minimum & Maximum & Mean & Std. Deviation \\
\hline GM & 1128 & 0.01 & 0.73 & 0.34 & 0.12 \\
\hline PM & 1128 & -0.57 & 0.25 & 0.02 & 0.06 \\
\hline ISR & 1128 & 0.11 & 0.74 & 0.16 & 0.11 \\
\hline DII (days) & 1128 & 5.42 & 564.11 & 92.38 & 70.59 \\
\hline PER (\$1,000) & 1110 & 29.25 & 1893.77 & 275.65 & 268.05 \\
\hline PEC (\$1,000) & 1110 & 10.08 & 1775.90 & 199.42 & 225.93 \\
\hline
\end{tabular}

\section{RESEARCH HYPOTHESES}

Many academic papers (Leung et al., 2007; Visich et al., 2009; Rekik et al., 2009; Sarac et al., 2010; Zhu et al., 2012; Bhattacharya, 2012) argue that there are many advantages for RFID adoption: (1) cost saving effect, (2) revenue increase effect, and (3) inventory management efficiency effect. Decreases in labor cost can be made by reducing the physical counting of inventory and product scanning-error rate. Revenue increases can be made by prevention of theft, shrink, and inventory write-off as well as decreased counterfeiting and decrease in returns (Veeramani, Tang, \& Gutierrez, 2008). Combined effects of cost-saving and revenue increase definitely affects profit increase. RFID adoption can also allow improved inventory management accuracy and responsiveness through real time inventory information (European Commission Joint Research Centre, 2007). This study tests whether RFID adoption gives benefits to adopting retailers in efficiency and profitability. First, it tests whether the mean difference of the above six financial ratios is significant between RFID companies and non-RFID companies, and second, it tests whether the mean difference of RFID adopted companies between pre-RFID and post-RFID is equal to zero. In addition, there is linear relationship estimated: one for two efficiency ratios about inventory and costs, and profitability. Table 4 summarizes the three hypotheses listed below:

$\mathbf{H}_{1}$ : $\quad$ Retail companies with RFID technology show stronger signs of performance in financial ratios when compared to those of non-RFID retail companies.

$\mathbf{H}_{2}$ : $\quad$ Retail companies with RFID technology show stronger signs of performance in financial ratios than before they had adopted it.

$\mathbf{H}_{3}$ : $\quad$ A significant linear relationship exists between efficiencies of inventory management and costs for retail companies and their profitability. 
Table 4: Summary of Hypotheses

\begin{tabular}{|c|c|c|c|c|c|}
\hline Hypothesis & & Ho & Ha & Grouping & Number of Companies \\
\hline \multirow{2}{*}{$\mathrm{H}_{1}$} & $\begin{array}{c}\text { GM } \\
\text { PM PER }\end{array}$ & $\mu_{\mathrm{RFID}}=\mu_{\text {non-RFID }}$ & $\begin{array}{c}\mu_{\text {RFID }}> \\
\mu_{\text {non-RFID }}\end{array}$ & \multirow{2}{*}{ RFID vs. Non-RFID } & \multirow{2}{*}{ All (141) } \\
\hline & $\begin{array}{c}\text { ISR } \\
\text { DII PEC }\end{array}$ & $\mu_{\mathrm{RFID}}=\mu_{\text {non-RFID }}$ & $\begin{array}{l}\mu_{\text {RFID }}< \\
\mu_{\text {non-RFID }}\end{array}$ & & \\
\hline \multirow{2}{*}{$\mathrm{H}_{2}$} & $\begin{array}{c}\text { GM } \\
\text { PM } \\
\text { PER }\end{array}$ & $\mu_{\text {post-RFID }}=\mu_{\text {pre- }}$ & $\begin{array}{c}\mu_{\text {post-RFID }}> \\
\mu_{\text {pre-RFID }}\end{array}$ & \multirow{2}{*}{ post-RFID vs. pre-RFID } & \multirow{2}{*}{ RFID only (24) } \\
\hline & $\begin{array}{l}\text { ISR } \\
\text { DII } \\
\text { PEC }\end{array}$ & $\mu_{\text {post-RFID }}=\mu_{\text {pre- }}$ & $\begin{array}{c}\mu_{\text {post-RFID }}< \\
\mu_{\text {pre-RFID }}\end{array}$ & & \\
\hline $\mathrm{H}_{3}$ & \multicolumn{2}{|c|}{$\begin{array}{c}\beta_{1}=\beta_{2}=\beta_{3}=0 \\
\beta_{1}: \text { Inventory efficiency } \\
\beta_{2}: \text { Cost efficiency } \\
\beta_{3}: \text { RFID adoption }\end{array}$} & $\mathrm{H}_{3 \mathrm{O}}$ is not true & & All (141) \\
\hline
\end{tabular}

\section{RESULTS}

\subsection{Results from Testing $\mathrm{H}_{1}$}

For Hypothesis $\mathrm{H}_{1}$, independent samples T-test compares the mean values of the financial ratios for RFID companies and non-RFID companies. The total number of observations in this test is 564, which is made by 141 retail companies for four years since 2008. To compare them, Levene's test is needed to check whether two samples have homogeneous variance. Among the six financial ratios, except ISR, no ratio has homogeneous variance; therefore, the five ratios are tested without the assumption of equal variance. The alternate hypothesis is that RFID companies have a higher ratio in GM, PM, and PER and a lower ratio in ISR, DII, and PEC. Table 5 presents group statistics of six ratios of both RFID companies and non-RFID companies.

Table 5: Statistics for RFID and Non-RFID Companies

\begin{tabular}{|l|c|c|c|c|}
\hline \multirow{2}{*}{ Ratios } & Group & $\mathbf{N}$ & Mean & Std. Deviation \\
\hline \multirow{2}{*}{ GM } & RFID & 96 & 0.33 & 0.11 \\
\cline { 2 - 5 } & non-RFID & 468 & 0.34 & 0.12 \\
\hline \multirow{2}{*}{ PM } & RFID & 96 & 0.02 & 0.04 \\
\cline { 2 - 5 } & non-RFID & 468 & 0.02 & 0.06 \\
\cline { 2 - 5 } & RFID & 96 & 0.15 & 0.11 \\
\cline { 2 - 5 } DII (days) & non-RFID & 468 & 0.16 & 34.11 \\
\cline { 2 - 5 } & RFID & 96 & 96.14 & 78.85 \\
\cline { 2 - 5 } PER $(\$ 1,000)$ & non-RFID & 468 & 216.92 & 115.09 \\
\hline \multirow{2}{*}{ PEC $(\$ 1,000)$} & RFID & 96 & 302.18 & 297.68 \\
\cline { 2 - 5 } & non-RFID & 468 & 153.73 & 100.02 \\
\hline
\end{tabular}

In profitability, no ratio of RFID companies is significantly higher than that of non-RFID companies at a $5 \%$ significance level. In inventory management efficiency, RFID companies have a significantly lower mean value of DII than the non-RFID companies at a 1\% significance level, but there is no significant evidence of lower ISR for RFID companies. In per employee efficiency, RFID companies have a significantly lower PEC at a $1 \%$ significance level, but non-RFID companies have a significantly higher PER, which means that RFID technology has a significant impact on cost efficiency, but not on revenue efficiency. For the inventory management efficiency, the mean value of DII in RFID is 71 days and the mean value of DII in non-RFID is 96 days (see Table 5). 24 days of difference in DII exist between RFID and non-RFID. Therefore, the $\mathrm{H}_{1}$ is partially supported. Table 6 summarizes the results of comparing two groups of data set. 
Table 6: Independent Samples T-test Result for RFID vs. Non-RFID

\begin{tabular}{|l|c|c|c|c|c|c|}
\hline & GM & PM & ISR & DII & PER & PEC \\
\hline Mean difference & -0.01 & 0.00 & -0.01 & -24.79 & -81.98 & -61.90 \\
\hline Equal variances assumed & No & No & Yes & No & No & No \\
\hline T-statistic & -0.45 & 0.83 & -1.21 & -4.85 & -4.71 & -4.23 \\
\hline Degree of freedom & 154 & 189 & 562 & 334 & 387 & 366 \\
\hline P-value (1-tale) & 0.67 & 0.20 & 0.11 & 0.00 & 1.00 & 0.00 \\
\hline$\alpha$ & $5 \%$ & $5 \%$ & $5 \%$ & $1 \%$ & $5 \%$ & $1 \%$ \\
\hline Reject Ho & No & No & No & Yes & No & Yes \\
\hline
\end{tabular}

\subsection{Results from Testing $\mathrm{H}_{2}$}

In testing $\mathrm{H}_{2}, 24$ RFID company data are used. The total number of data for eight years is 192 , which is grouped by pre-RFID and post-RFID. Each RFID company has a different RFID technology adoption year. Therefore, each one has a different combination of pre-RFID data and post-RFID data. In summary, 45 pre-RFID data and 147 post-RFID data are used. $\mathrm{H}_{2}$ is also tested by the independent samples T-test. Table 7 describes statistics for the six ratios in each group.

Table 7: Statistics for Pre-RFID and Post-RFID Companies

\begin{tabular}{|c|c|c|c|c|}
\hline Ratios & Group & $\mathbf{N}$ & Mean & Std. Deviation \\
\hline \multirow{2}{*}{ GM } & post-RFID & 147 & 0.32 & 0.11 \\
\hline & pre-RFID & 45 & 0.35 & 0.10 \\
\hline \multirow{2}{*}{ PM } & post-RFID & 147 & 0.03 & 0.04 \\
\hline & pre-RFID & 45 & 0.04 & 0.03 \\
\hline \multirow{2}{*}{ ISR } & post-RFID & 147 & 0.15 & 0.13 \\
\hline & pre-RFID & 45 & 0.15 & 0.06 \\
\hline \multirow{2}{*}{ DII (days) } & post-RFID & 147 & 69.93 & 33.39 \\
\hline & pre-RFID & 45 & 86.13 & 37.40 \\
\hline \multirow{2}{*}{$\operatorname{PER}(\$ 1,000)$} & post-RFID & 147 & 217.74 & 112.58 \\
\hline & pre-RFID & 45 & 168.44 & 70.97 \\
\hline \multirow{2}{*}{$\operatorname{PEC}(\$ 1,000)$} & post-RFID & 147 & 155.85 & 99.30 \\
\hline & pre-RFID & 45 & 114.16 & 61.13 \\
\hline
\end{tabular}

Levene's test is also needed for the six financial ratios. All six ratios have homogeneous variances; therefore, the ratios are tested with the assumption of equal variance. The alternate hypothesis is that mean values of post-RFID might have a higher ratio in GM, PM, and PER and a lower ratio in ISR, DII, and PEC than pre-RFID.

The DII and PER of post-RFID are better than those of pre-RFID at a $1 \%$ significance level. On the contrary, the PEC of pre-RFID is significantly lower at a $1 \%$ significance level and GM and PM of pre-RFID are higher than that of post-RFID at 5\% and $1 \%$ significance level, respectively. RFID technology adoption needs huge set-up costs including costs of hardware and software as well as system integration cost. The implementation costs of RFID technology affect the cost efficiency and profitability in its early years, which might affect profitability ratios and cost efficiency ratio. For the inventory management efficiency, the mean value of DII in pre-RFID is 86 days and the mean value of DII in post-RFID is 69 days (see Table 7). There are 16 days reduced of staying in inventory since the RFID technology adoption. Therefore, $\mathrm{H}_{2}$ is partially supported. Table 8 summarizes the results of testing $\mathrm{H}_{2}$.

Table 8: T-test Result for Companies with Post-RFID and Pre-RFID

\begin{tabular}{|l|c|c|c|c|c|c|}
\hline & GM & PM & ISR & DII & PER & PEC \\
\hline Mean difference & -0.03 & -0.01 & 0.01 & -16.20 & 49.31 & 41.69 \\
\hline Equal Variances Assumed & Yes & Yes & Yes & Yes & Yes & Yes \\
\hline T-statistic & -1.63 & -2.30 & 0.31 & -2.77 & 2.71 & 2.66 \\
\hline Degree of freedom & 190 & 190 & 190 & 190 & 190 & 190 \\
\hline P-value & 0.95 & 0.99 & 0.62 & 0.00 & 0.00 & 1.00 \\
\hline$\alpha$ & $5 \%$ & $5 \%$ & $5 \%$ & $1 \%$ & $1 \%$ & $5 \%$ \\
\hline Reject Ho & No & No & No & Yes & Yes & No \\
\hline
\end{tabular}




\subsection{Results from Testing $\mathrm{H}_{3}$}

\subsubsection{Base Model}

A linear regression analysis is used to determine the validity of $\mathrm{H}_{3}$. This study uses both cross-sectional and time-series panel data. The total number of observations in the data set for testing $\mathrm{H}_{3}$ is 564 , which is data for 141 companies for 4 years from 2008 through 2011. Estimating the panel data regression model by ordinary least square might provide a biased solution caused by unobserved heterogeneity (Dougherty, 2006). To overcome this possible problem, two approaches are offered: fixed effect and random effect. According to Greene (2012), while the fixed effect assumes that individual heterogeneity is correlated with independent variables, the random effect assumes that the individual heterogeneity is uncorrelated with the independent variables. Jerry A. Hausman has a test for determining which model is appropriate.

RFID retailers can influence their profits through three approaches: reduced inventory can decrease cost, reduced labor can decrease cost, and reduced stockout can increase revenue (Soon \& Gutierrez, 2008). Ratios from inventory management efficiency group and per-employee efficiency group can be independent variables to estimate a relationship with a ratio from the profitability group. Therefore, ISR, DII, PEC, and PER can be candidates for independent variables for this regression analysis. However, because of the high correlation between PEC and PER, -0.9786 and between DII and ISR, -0.8564 , ISR and PEC are chosen for the two independent variables to predict ratios for profitability as a dependent variable. In addition to these two variables, a dummy variable, RFID, is introduced. If a company adopts RFID technology, then its value is 1 ; otherwise, the value is 0 , which explains the relationship between adoption of RFID and ratios for profitability. To choose a dependent variable among the two ratios about profitability (GM and PM), the two regression models with each of two profit ratios are estimated with three independent variables (ISR, PEC, and RFID). In Table 9, the $R^{2}$ value of regression model (1) with GM is reasonably high enough compared to that of (2) and all p-values of the coefficients of the model (1) are acceptable within a 5\% significance level. Therefore, GM is chosen as a dependent variable in testing $\mathrm{H}_{3}$.

Table 9: Regression Analysis Result with Two Profit Ratios

\begin{tabular}{|l|c|c|c|c|c|c|c|c|}
\hline $\begin{array}{c}\text { Regression } \\
\text { Model }\end{array}$ & $\begin{array}{c}\text { Dependent } \\
\text { Variable }\end{array}$ & $\boldsymbol{R}^{2}$ & $\begin{array}{c}\text { F-stat } \\
(\boldsymbol{p} \text {-value })\end{array}$ & $\begin{array}{c}\text { Degree of } \\
\text { Freedom }\end{array}$ & $\begin{array}{c}\boldsymbol{\beta}_{\boldsymbol{0}} \\
(\boldsymbol{p} \text {-value })\end{array}$ & $\begin{array}{c}\boldsymbol{\beta}_{1} \\
(\boldsymbol{p} \text {-value })\end{array}$ & $\begin{array}{c}\boldsymbol{\beta}_{2} \\
(\boldsymbol{p} \text {-value })\end{array}$ & $\begin{array}{c}\boldsymbol{\beta}_{3} \\
(\boldsymbol{p} \text {-value })\end{array}$ \\
\hline$(1)$ & $\mathrm{GM}$ & 0.387 & $\begin{array}{c}117.60 \\
(0.000)\end{array}$ & 3,560 & $\begin{array}{c}0.375 \\
(0.00)\end{array}$ & $\begin{array}{c}0.163 \\
(0.00)\end{array}$ & $\begin{array}{c}-0.000 \\
(0.00)\end{array}$ & $\begin{array}{c}-0.024 \\
(0.03)\end{array}$ \\
\hline$(2)$ & $\mathrm{PM}$ & 0.023 & $\begin{array}{c}4.37 \\
(0.005)\end{array}$ & 3,560 & $\begin{array}{c}0.034 \\
(0.00)\end{array}$ & $\begin{array}{c}-0.052 \\
(0.02)\end{array}$ & $\begin{array}{c}-0.000 \\
(0.00)\end{array}$ & $\begin{array}{l}0.002 \\
(0.81)\end{array}$ \\
\hline
\end{tabular}

Therefore, the following is a base regression model for testing $\mathrm{H}_{3}$ :

$G M_{i t}=\beta_{0}+\beta_{1} I S R_{i t}+\beta_{2} P E C_{i t}+\beta_{3} R F I D_{i t}+\varepsilon_{i t}$

For $\mathrm{i}=1 \sim 141$ companies and $\mathrm{t}=2008 \sim 2011$

This base regression model is built under the classical assumption of ordinary least squares to ignore the time and individual dimensions of the panel data. One of the assumptions of this model is homoskedasticity, or equal statistical variance. The Breusch-Pagan (BP) test is used to test the homoskedasticity assumption by running a regression with the squared residuals as a single dependent variable. Because the $p$-value from the BP test is near zero, the null hypothesis of homoskedasticity is rejected with a $1 \%$ significance level. Therefore, this data qualifies as heteroskedastic. The problem with heteroskedasticity is that the $T$-statistics of coefficients cannot be relied upon because the estimated standard errors are biased. The heteroskedasticity-consistent, or HC, standard errors are proposed by Halbert White to fit models with heteroskedastic residuals and correct standard errors (White, 1980). The output from the HC standard errors has the same coefficient with different $T$-statistics and $p$-values of the coefficients of regression model.

The significant relationship is present in the model at a $1 \%$ significance level, but its $R^{2}$ is relatively low by 0.39 . The significance of coefficients of ISR and PEC, are present at $1 \%$ significance level and that of RFID is at $5 \%$. Variance Inflation Factor, or VIF, is a measure of multicollinearity, which is a statistical phenomenon caused by 
highly correlated independent variables. The VIF values of three variables are less than 1.1, so the variables do not have multicollinearity.

However, the Durbin-Watson (DW) statistic, $d$, is quite low, 0.73. DW $d$ must be compared to two critical $d$ values: $d_{L}$ and $d_{H}$. According to the table of extended critical values for the DW test (http://www.stanford.edu/ clint/bench/dwcrit.htm), with four independent variables including intercept and 550 observations, the $1 \%$ one-tailed critical values are $d_{L}=1.79$ and $d_{H}=1.81$. If the $d$ is less than $d_{L}$, the null hypothesis, or no evidence of positive correlation, is rejected. If the $d$ is greater than $d_{H}$, the null hypothesis cannot be rejected. Because $d<d_{L}$, this model should have an autocorrelation problem. To overcome that in panel data, the authors must choose one of the above approaches, fixed effect or random effect.

To do the Hausman Test, the individual dummy variables must be introduced in Equation (1). The null hypothesis for the Hausman test is no difference of results between the fixed effect model and the random effect model. Because of the near zero $p$-value from the Hausman test, the null hypothesis is rejected. Therefore, the fixed effect model is more appropriate. Table 10 summarizes the test results from the base model.

Table 10: Test Statistics and Result for Base Model

\begin{tabular}{|l|c|c|c|}
\hline \multicolumn{1}{|c|}{ Test Name } & Test Value & Critical Value & Result \\
\hline Breusch-Pagan Test & $\begin{array}{c}B P=26.22 \\
p \text {-value }=8.565 \mathrm{e}-6\end{array}$ & $\alpha=0.01$ & Heterokedasticity \\
\hline Durbin-Watson Test & $\begin{array}{c}D W d=0.73 \\
p \text {-value }<2.2 \mathrm{e}-16\end{array}$ & $\begin{array}{c}d_{L}(n=550, \alpha=0.01, k=4)=1.79126 \\
d_{H}(n=550, \alpha=0.01, k=4)=1.81312\end{array}$ & Autocorrelation \\
\hline Hausman Test & $\begin{array}{c}\text { Chi-square }=40.32, \\
p \text {-value }=9.1 \mathrm{e}-09\end{array}$ & $\alpha=0.01$ & Fixed Effect \\
\hline VIF & $\begin{array}{c}1.065 \text { (ISR) } \\
1.074 \text { (PEC) } \\
1.016 \text { (RFID) }\end{array}$ & 10 & No Multicollinearity \\
\hline
\end{tabular}

\subsubsection{Fixed Effect Model}

Baltagi (2005) explains a procedure to estimate the fixed effect regression model. The model adds some dummy variables in each step. There are two kinds of dummy variables: intercept dummy and slope dummy. The intercept dummy variable has an addictive form and the slope dummy has a productive form with independent variables. Since the panel data in this study have two dimensions, individual company and time, the dummy variables used in this model are dummy variables for both individual and time dimensions. For example, $D_{i}$ and $T_{i}$ are intercept dummy variables for each retailers and each year respectively, and $I S R_{i} * D_{i}, P E C_{i} * D_{i}, I S R_{i} * T_{i}$, and $P E C_{i} * T_{i}$ are productive forms of slope dummy variables. The following are six models used for the development of fixed model with the dummy variables:

- $\quad$ Model 1: Base regression model with no dummy variable.

- $\quad$ Model 2: Adding individual intercept dummies $\left(D_{i}\right)$ to Model 1.

- $\quad$ Model 3: Adding time intercept dummies $\left(T_{i}\right)$ to Model 2.

- $\quad$ Model 4: Adding individual slope dummies for the first independent variable $\left(I S R_{i} * D_{i}\right)$ to Model 2.

- $\quad$ Model 5: Adding individual slope dummies for the next independent variable $\left(P E C_{i} * D_{i}\right)$ to Model 4.

- $\quad$ Model 6: Adding time slope dummies $\left(I S R_{i} * T_{i} \& P E C_{i} * T_{i}\right)$ for each independent variable as well as time intercept dummies $\left(T_{i}\right)$ to Model 5.

There are 140 intercept dummy variables for individual companies and 3 time intercept dummy variables. In addition, there are 140 individual slope dummy variables for ISP and $P E C$ and 3 slope time dummy variables for $I S R$ and PEC. The total number of dummy variables that are used in Model 6 is 429. Table 11 presents the six fixed effect regression models. 
Table 11: Fixed Effect Regression Models

\begin{tabular}{|l|l|}
\hline Model No. & \multicolumn{1}{c|}{ Regression Model } \\
\hline$(1)$ & $G M_{i t}=\beta_{0}+\beta_{I} I S R_{i t}+\beta_{2} P E C_{i t}+\beta_{3} R F I D_{i t}+\varepsilon_{i t}$ \\
\hline$(2)$ & $G M_{i t}=\beta_{0}+\beta_{0 i} D_{i}+\beta_{I} I S R_{i t}+\beta_{2} P E C_{i t}+\beta_{3} R F I D_{i t}+\varepsilon_{i t}$ \\
\hline$(3)$ & $G M_{i t}=\beta_{0}+\beta_{0 i} D_{i}+\beta_{0 t} T_{\mathrm{t}}+\beta_{1} I S R_{i t}+\beta_{2} P E C_{i t}+\beta_{3} R F I D_{i t}+\varepsilon_{i t}$ \\
\hline$(4)$ & $G M_{i t}=\beta_{0}+\beta_{0 i} D_{i}+\beta_{I} I S R_{i t}+\beta_{2} P E C_{i t}+\beta_{3} R F I D_{i t}+\beta_{l i} I S R_{i}^{*} D_{i}+\varepsilon_{i t}$ \\
\hline$(5)$ & $G M_{i t}=\beta_{0}+\beta_{0 i} D_{i}+\beta_{I} I S R_{i t}+\beta_{2} P E C_{i t}+\beta_{3} R F I D_{i t}+\beta_{I i} I S R_{i} * D_{i}+\beta_{2 i} P E C_{i} * D_{i}+\varepsilon_{i t}$ \\
\hline$(6)$ & $G M_{i t}=\beta_{0}+\beta_{0 i} D_{i}+\beta_{0 t} T_{t}+\beta_{I} I S R_{i t}+\beta_{2} P E C_{i t}+\beta_{3} R F I D_{i t}+\beta_{l i} I S R_{i} * D_{i}+\beta_{2 i} P E C_{i} * D_{i}+\beta_{1 t} I S R_{t} * T_{t}+\beta_{2 t} P E C_{t} * T_{t}+\varepsilon_{i t}$ \\
\hline
\end{tabular}

Table 12 presents the results of the above six fixed-effect models. The $p$-values of all six models from the BP tests are less than 0.01 , so the six models qualify as heteroskedastic. The coefficients of three independent variables listed in Table 12 are based on HC standard errors.

Table 12: Comparison of Results of Six Fixed Effect Models

\begin{tabular}{|c|c|c|c|c|c|c|c|c|c|c|}
\hline $\begin{array}{c}\text { Model } \\
\text { No. }\end{array}$ & $\begin{array}{c}\text { Number } \\
\text { of } \\
\text { Variables }\end{array}$ & $\begin{array}{l}\text { BP Test } \\
\text { p-value }\end{array}$ & $\begin{array}{c}\text { Durbin } \\
\text { Watson } \\
d\end{array}$ & $\mathbf{R}^{2}$ & $\begin{array}{c}\text { F-Stat } \\
\text { (p-value) }\end{array}$ & $\begin{array}{l}\text { Degree of } \\
\text { freedom }\end{array}$ & $\begin{array}{c}\boldsymbol{\beta}_{0} \\
\text { (p-value) }\end{array}$ & $\begin{array}{c}\beta_{1} \\
\text { (p-value) }\end{array}$ & $\begin{array}{c}\boldsymbol{\beta}_{2} \\
\text { (p-value) }\end{array}$ & $\begin{array}{c}\boldsymbol{\beta}_{3} \\
\text { (p-value) }\end{array}$ \\
\hline$(1)^{*}$ & 4 & 0.000 & 0.725 & 0.3866 & $\begin{array}{l}117.6 \\
(0.00) \\
\end{array}$ & 3,560 & $\begin{array}{c}0.3753 \\
(0.00) \\
\end{array}$ & $\begin{array}{c}0.1629 \\
(0.00)\end{array}$ & $\begin{array}{c}-0.0003 \\
(0.00)\end{array}$ & $\begin{array}{c}-0.0243 \\
(0.03)\end{array}$ \\
\hline$(2)^{*}$ & 144 & 0.000 & 1.891 & 0.9787 & $\begin{array}{l}134.8 \\
(0.00) \\
\end{array}$ & 143,420 & $\begin{array}{c}0.4094 \\
(0.00) \\
\end{array}$ & $\begin{array}{c}-0.1161 \\
(0.15)\end{array}$ & $\begin{array}{c}-0.0001 \\
(0.00)\end{array}$ & $\begin{array}{c}0.0167 \\
(0.00) \\
\end{array}$ \\
\hline$(3)^{*}$ & 147 & 0.000 & 1.885 & 0.9792 & $\begin{array}{l}134.2 \\
(0.00)\end{array}$ & 146,417 & $\begin{array}{c}0.4083 \\
(0.00)\end{array}$ & $\begin{array}{c}-0.1112 \\
(0.16)\end{array}$ & $\begin{array}{c}-0.0001 \\
(0.00)\end{array}$ & $\begin{array}{c}0.0126 \\
(0.00)\end{array}$ \\
\hline$(4)^{*}$ & 284 & 0.002 & 2.090 & 0.9876 & $\begin{array}{c}78.6 \\
(0.00) \\
\end{array}$ & 283,280 & $\begin{array}{c}0.4888 \\
(0.00) \\
\end{array}$ & $\begin{array}{c}-0.7610 \\
(0.37) \\
\end{array}$ & $\begin{array}{c}-0.0001 \\
(0.00) \\
\end{array}$ & $\begin{array}{c}0.0198 \\
(0.00) \\
\end{array}$ \\
\hline$(5)^{*}$ & 424 & 0.010 & 2.559 & 0.9965 & $\begin{array}{c}94.5 \\
(0.00) \\
\end{array}$ & 423,140 & $\begin{array}{c}0.5330 \\
(0.00) \\
\end{array}$ & $\begin{array}{c}-1.5672 \\
(0.00)\end{array}$ & $\begin{array}{c}0.0008 \\
(0.29)\end{array}$ & $\begin{array}{r}0.0362 \\
(0.00) \\
\end{array}$ \\
\hline$(6)^{*}$ & 433 & 0.009 & 2.569 & 0.9969 & $\begin{array}{c}96.3 \\
(0.00)\end{array}$ & 432,131 & $\begin{array}{c}0.4943 \\
(0.00)\end{array}$ & $\begin{array}{c}-1.7232 \\
(0.00)\end{array}$ & $\begin{array}{r}0.0017 \\
(0.04)\end{array}$ & $\begin{array}{c}0.0349 \\
(0.00)\end{array}$ \\
\hline
\end{tabular}

Note: * p-values from $\mathrm{HC}$ standard errors

Except Model (1), the other models do not have autocorrelation problems because their $d$ values are greater than $d_{L}$ (1.88). In the Durbin-Watson d statistic table, there is no DW $d$ value for 564 observations and the maximum number of variable is 21 , thus the most similar number is chosen, which is 550 observations and 21 variables with 0.01 significance. Considering p-values of coefficients in the five models, (2) through (6), Model (6) is the most robust. Its intercept is 0.4943 , and $-1.7232,0.0017$, and 0.0349 are the coefficients of variables ISR, PEC, and RFID, meaning that, first, the values of ISR have much more influence to the GM than those of PEC, and, second, the lesser values of ISR is, the higher the GM becomes. In addition, RFID companies have a higher GM than non-RFID companies by 0.0349 when values of ISR and PEC are constant. Therefore, the regression results indicates that maintaining a lower level of inventory has a positive effect on higher GM, and lower per-employee costs do not show a significant effect on increasing profitability.

\section{CONCLUSION}

Ten years have passed since Wal-Mart's public announcement about its RFID technology adoption plan in 2003. Some large competitors of Wal-Mart in the U.S. retail industry jumped on the trend of RFID technology adoption. The RFID companies are big companies in the U.S. retail industry. Based on the average amount of annual sales of 141 retail companies in 2011, the average annual sales of RFID companies is $\$ 52.3$ billion and that of nonRFID companies is $\$ 4.5$ billion. Among 141 U.S. retail companies, the 24 RFID retail companies' market share is $70.5 \%$ and that of the 117 non-RFID companies' is only $29.5 \%$. Even if there are only $17 \%$ (24 out of 141) of RFID companies in the retail industry, the effect on the industry is much larger due to the influence of their market power. As other papers mentioned, despite the fact that the RFID companies are setting the market trends, the smaller companies are fiscally unable to adopt RFID or are unwilling due to the smaller companies' inability to take chances given the state of the economy and the weak fiscal foundations these small companies have.

This study investigates the role of RFID technology in the U.S. retail industry. It is a challenge to determine when to adopt RFID technology and its new business processes. In the early stage of new investment like RFID 
technology, cash flow is below zero because of the up-front set up cost. Ratios for profitability are very sensitive to U.S. economic crisis. Such economic situation worsens the payback period to make break-even cash flow. Among the results of two T-tests with experiment groups (RFID, post-RFID) against control groups (non-RFID, pre-RFID), only DII is always better in the experiment groups. Moreover, for all profitability ratios, there is no clear evidence that ratios of profitability in the experiment group are better than those in the control groups, which is a different result from the Chang's article (2011) claiming that adoption of RFID technology contributed to improve financial performance in the manufacturing industry. For the per employee efficiency, RFID companies have better cost efficiency than non-RFID companies and RFID companies have improved sales efficiency after they adopted the technology. Therefore, as other academic papers argue, RFID technology adoption severely affects inventory management efficiency. However, there is no improvement of RFID technology adoption in profitability ratios and there is no consistent result of per employee efficiency ratios from the two tests.

There is a panel data regression analysis, which tries to find a robust relationship for profitability and efficiencies of cost and inventory management. There are positive results about how RFID technology adoption affects their profit. A strong relationship exists between inventory management efficiency and profitability but a weak relationship exists between cost efficiency and profitability.

The results from T-tests and regression analyses are affected by the U.S. economy. There has been a financial crisis in the U.S. economy during 2007-2008. In 2008 and 2009, there are negative growth rates in U.S. GDP growth $(-0.3 \% \&-3.1 \%)$ and U.S. retail sales total are lower than they are in the previous year. This might be the reason why outputs from testing ratios are not consistent when comparing two groups and outputs from the regression analysis do not show a strong relationship between cost efficiency and profitability.

In summary, it could be stated that introducing RFID reduces a number of days products stay as inventories but we do not know yet if RFID technology adoption also contributes to profitability and per employee efficiency in U.S. retail industry. This can be explained by the fact that while the RFID technology can directly influence the efficiency of inventory management, the effects on profitability by RFID technology can be impacted indirectly through the efficiency of inventory management. It would take more time to find an objective improvement of RFID technology adoption.

\section{AUTHOR INFORMATION}

Seungjae Shin received a Ph.D. in Information Sciences (2003) at the University of Pittsburgh and a Ph.D. in Industrial and Systems Engineering (2013) at Mississippi State University. He is currently an Associate Professor of Information Systems and Supply Chain Management at Mississippi State University, Meridian. His research areas are telecommunications industry analysis and logistics. Seungjae Shin, Mississippi State University, 2212 5th Street, Meridian, MS, 39301 USA. E-mail: sshin@meridian.msstate.edu (Corresponding Author)

Burak Eksioglu received his Ph.D. in 2002 from the Department of Industrial and Systems Engineering at the University of Florida. He is currently an Associate Professor of Industrial and Systems Engineering at Mississippi State University. His research efforts are focused on operations research, supply chain optimization, disaster management, heuristics optimization, and logistics and transportation. Burak Eksioglu, Mississippi State University, 260 McCain Hall, Miss. State, MS 39762 USA. E-mail: beksioglu@ise.msstate.edu

\section{REFERENCES}

1. Baltagi, B. H. (2005). Econometric analysis of panel data $\left(3^{\text {rd }}\right.$ Ed.). New York, NY: Wiley.

2. Bartlett, R. (2008). Going private but staying public: Reexamining the effect of Sarbanes-Oxley on firms' going-private decisions. Retrieved from http://www.law.berkeley.edu/files/bclbe/going_private_ robert_Bartlett.pdf

3. Bhattacharya, M. (2012). Impact of RFID on the retail value chain: An exploratory study using a mixed method approach. Journal of Technology, Management \& Innovation, 7(4), 36-49.

4. Chang, Y. B. (2011). Does RFID improve firms' financial performance? An empirical analysis. Information Technology and Management, 12(3), 273-85. 
5. Collins, J. D., Worthington, W. J., Reyes, P. M., \& Romero, M. (2010). Knowledge management, supply chain technologies and firm performance. Management Research Review, 33(10), 947-60.

6. Dougherty, C. (2006). Introduction to econometric ( $3^{\text {rd }}$ Ed.). New York: Oxford University Press.

7. Edwards, J. (2008). EPC's tipping point. RFID Journal. Retrieved from http://www.rfidjournal.com/ articles/view?4398

8. European Commission Joint Research Centre. (2007). RFID technologies: Emerging Issues, challenges and policy options. Retrieved from ftp://ftp.jrc.es/pub/EURdoc/eur22770en.pdf

9. $\quad$ Fraser, L. M., \& Ormiston, A. (2010). Understading financial statements $\left(9^{\text {th }}\right.$ Ed.). Upper Saddle River, NJ: Prentice Hall.

10. Gaukler, G. M. (2011). Item-level RFID in a retail supply chain. Production and Operations Management, 16(1), 65-76.

11. Graff, R. (2008). Threat of delisting grows at NYSE, but NASDAQ suspends requirements. Retrieved from http://news.medill.northwestern.edu/chicago/news.aspx?id=107543

12. Greene, W. H. (2012). Econometric analysis ( $7^{\text {th }}$ Ed.). Upper Saddle River, NJ: Prentice Hall.

13. Hardgrave, B. C., Langford, S., Waller, M., \& Miller, R. (2008). Measuring the impact of RFID on out of stock at Wal-Mart. MIS Quarterly Executive, 7(4), 181-92.

14. Hunt, D., Puglia, A., \& Puglia, M. (2007). Wal-Mart RFID initiative, in RFID - A guide to radio frequency identification, Inc. Hoboken, NJ: John Wiley \& Sons. Retrieved from http://onlinelibrary.wiley.com/ doi/10.1002/9780470112250.app1/pdf

15. Jeong, B. K., \& Lu, Y. (2008). The impact of radio frequency identification (RFID) investment announcements on the market value of the firm. Journal of Theoretical and Applied Electronic Commerce Research, 3(1), 41-54.

16. Kok, A. G., van Donselaar, K. H., \& van Woensel, T. (2008). A break-even analysis of RFID technology for inventory sensitive to shrinkage. International Journal of Production Economics, 112, 521-31.

17. Lee, I., \& Lee B. C. (2010). An investment evaluation of supply chain RFID technologies: A normative modeling approach. International Journal of Production Economics, 125, 313-23.

18. Leung, Y. T., Cheng, F., Lee, Y. M., \& Hennessy, J. J. (2007). A tool set for exploring the value of RFID in a supply chain. In H. Jung, B. Jeong, \& F. F. Chen (eds), Trend in supply chain design and management (pp. 49-70). Springe series in advanced manufacturing.

19. Li, S., Godon, D., \& Visich J. K. (2010). An exploratory study of RFID implementation in the supply chain. Management Research Review, 33(10), 1005-15.

20. Malone, R. (2005). RFID mandates: Gorillas in the mist. Retrieved from http://www.inboundlogistics.com/ $\mathrm{cms} /$ article/rfid-mandates-gorillas-in-the-mist

21. McBeath, B. (2013). The explosion of retail item-level RFID: A foundation for the retail revolution. Retrieved from https://www.rfidjournal.com/whitepapers/download?432

22. Osyk, B. A., Vijayaraman, B. S., Srinivasan, M., \& Dey, A. (2012). RFID adoption and implementation in warehousing. Management Research Review, 35(10), 904-26.

23. Park, K. S., Koh, C. E., \& Nam, K. (2010). Perceptions of RFID technology: A cross-national study. Industrial Management \& Data Systems, 110(5), 682-700.

24. Rekik, Y., Sahin, E., \& Dallery, Y. (2009). Inventory inaccuracy in retail stores due to theft: An analysis of benefits of RFID. International Journal of Production Economics, 118, 189-98.

25. RFID Journal. (2003). Wal-Mart expands RFID mandate. Retrieved from http://www.rfidjournal.com/ article/view/539

26. RFID Journal. (2004). Target issues RFID mandate. Retrieved from http://www.rfidjournal.com/ article/view/802.

27. Sarac, A., Absi, N., \& dauzere-Peres, S. (2010). A literature review on the impact of RFID technologies on supply chain management. International Journal of Production Economics, 128, 77-95.

28. Senbet, L. W., \& Gande, A. (2009). Financial crisis and stock markets: Issues, impact, and policies. Retrieved from http://www.rhsmith.umd.edu/faculty/lsenbet/Dubai\%20project\%20-\%20financia\%20crisisSenbet-final-09.pdf

29. Soon, C., \& Gutierrez, J. A. (2008). Effects of the RFID mandate on supply chain management. Journal of Theoretical and Applied Electronic Commerce Research, 3(1), 81-91. 
30. Supply Chain Digest. (2013). JC Penny backs off RFID Rollout pace, as getting all the parts together proves a little more complicated than first thought. Retrieved from http://www.scdigest.com/ontarget/1301-29-1.php?cid=6669

31. Supply Insight Inc. (2006). Retail mandate for RFID. Retrieved from http://www.supplyinsight.com/ Retail_RFID_Mandates.htm

32. Veeramani, D., Tang, J., \& Gutierrez, A. (2008). A framework for assessing the value of RFID implementation by tier-one suppliers to major retailers. Journal of Theoretical and Applied Electronic Commerce Research, 3(1), 55-70.

33. Visich, J. K., Li, S., Khumawala, B. M., \& Reyes, P. M. (2009). Empirical evidence of RFID impacts on supply chain performance. International Journal of Operations and Production Management, 29(12), 1290-315.

34. Weier, M. H. (2008). Wal-Mart gets tough on RFID. InformationWeek. Retrieved from http://www.informationweek.com/wal-mart-gets-tough-on-rfid/205900561

35. White, H. (1980). A heteroskedasticity-consistent covariance matrix and a direct test for heteroskedasticity. Econometrica, 48(4), 817-38.

36. Whiting, R. (2004). FDA pushes to drug industry to adopt RFID. InformationWeek. Retrieved from http://www.informationweek.com/fda-pushes-drug-industry-to-adopt-rfid/17800155?queryText=FDA

37. Zelbst, P. J., Green, K. W., \& Sower, V. E. (2010). Impact of RFID technology utilization on operational performance. Management Research Review, 33(10), 994-1004.

38. Zhu, X., Mukhopadhyay, S. K., \& Kurata, H. (2012). A review of RFID technology and its managerial application in different industries. Journal of Engineering and Technology Management, 29, $152-67$. 
NOTES 